\title{
124. Notes on the Chemotactic Response of Rhabditis filiformis Bütschli.
}

\author{
By Ryoseki TANIguchI. \\ Department of Hygiene, Tokyo Jikei-Kwai Medical College.
}

(Comm. by C. SASAKI, M.I.A., Oct. 12, 1933.)

On account of the occurrence in soils of several nemas worthy of notice from the agricultural and hygienic standpoints, it is of urgent necessity to study them from various angles. In this account merely a record is given of the chemotactic response of Rhabditis filiformis Bütschli, which is one of the most common species among soil nemas. The material here dealt with was that reared by Mr. Imamura, and it was first transferred to the agar-agar plate previously incubated at $37^{\circ} \mathrm{C}$. for twenty four hours with some saprophytic bacteria in the air. After five days' incubation numerous adults were demonstrated at $25^{\circ} \mathrm{C}$. and ca. $70 \%$ in humidity. In order to obtain some reliable data, only the material which was incubated for five days was employed throughout the course of this work.

On experimentation I prepared many pieces of $1 \%$ agar, each $2.5 \mathrm{~cm}$. long, $2.5 \mathrm{~cm}$. wide and $1 \mathrm{~cm}$. thick, and made a minute hole ( $2 \mathrm{~mm}$. in diameter and depth) on each piece by means of an ordinary platinum loop. Various kinds of chemicals were carefully put into the hole. After their gradual diffusion around the hole for a distance of $2 \mathrm{~mm}$., some twenty male and female nemas were set free outside of its diffused area, and their behaviour was observed under the microscope. At times the nemas intrude the diffused area and fall into the hole, while at other times they run away, having a distaste for chemicals. In the tables the former case is indicated by "positive" and the latter, by " negative." Every experiment was repeated at least three times and 20-30 individuals were used for each experiment. The temperature at which experiment was done varied from $21^{\circ} \mathrm{C}$. to $24^{\circ} \mathrm{C}$. and humidity from $55 \%$ to $75 \%$. The results of experiments are given in the following.

Here I deem it my duty to express my hearty thanks to Professor Y. Yasaki and Dr. R. Majima for invaluable advice and courtesies and also to Professor T. Kaburaki and Mr. S. Imamura of Zoological Institute, Faculty of Agriculture, Tokyo Imperial University, for many courteous acts. 
No. 8.] Notes on the Chemotactic Response of Rhabditis filiformis Bütschli. 433

a). Experiments with various kinds of acids and alkalies.-As may be evident from Tables I and II, the nema generally shows an attraction to acids more than to alkalies and to inorganic acids more than to organic.

TABLE I.

Effect of various kinds of acids on Rhabditis filiformis.

\begin{tabular}{|c|c|c|c|c|c|c|c|c|}
\hline \multirow{2}{*}{ Chemical } & \multicolumn{8}{|c|}{$5.0 \times$} \\
\hline & 1 & $2^{-1}$ & $2^{-2}$ & $2^{-3}$ & $2^{-4}$ & $2^{-5}$ & $2^{-6}$ & $2^{-7}$ \\
\hline Acidum hydrochloricum & - & - & - & + & + & + & + & + \\
\hline Acidum nitricum & - & - & - & + & + & + & + & + \\
\hline Acidum sulfuricum & - & - & + & + & + & + & + & + \\
\hline Acidum aceticum & - & - & - & - & + & + & + & + \\
\hline Acidum formicum ...... & - & - & - & - & - & - & - & + \\
\hline Acidum tartaricum .. & - & - & - & - & + & + & + & + \\
\hline Acidum oxalicum ... & - & - & - & - & + & + & + & + \\
\hline
\end{tabular}

TABLE II.

Effect of various kinds of alkalies on Rhabditis filiformis.

\begin{tabular}{|c|c|c|c|c|c|c|c|}
\hline \multirow{2}{*}{ Chemical } & \multicolumn{7}{|c|}{$5.0 x$} \\
\hline & 1 & $2^{-1}$ & $2^{-2}$ & $2^{-3}$ & $2^{-4}$ & $2^{-5}$ & $2^{-6}$ \\
\hline Natrium causticum & - & - & - & - & - & + & + \\
\hline Kali causticum & - & - & - & - & + & + & + \\
\hline Aqua ammoniae. & - & + & + & + & + & + & + \\
\hline
\end{tabular}

b). Experiments with various kinds of salts.-The behaviour of the nema operated on appears to be independent for most salts, exclusive of such chemicals as kalium permanganicum, argentum nitricum, hydrargyrum bichloratum, alumen and cuprum sulfuricum. To the solutions of kalium permanganicum $(0.02 \%)$, argentum nitricum $(0.003 \%)$, hydrargyrum bichloratum $(0.05 \%)$, alumen $(0.05 \%)$ and cuprum sulfuricum $(0.1 \%)$ the nema apparently shows a negative response, as may be seen from Table III. 
TABLE III.

Effect of various kinds of salts on Rhabditis filiformis.

\begin{tabular}{|c|c|c|c|c|c|c|c|c|c|}
\hline \multirow{2}{*}{ Chemical } & \multicolumn{9}{|c|}{$5.0 \times$} \\
\hline & 1 & $2^{-1}$ & $2^{-2}$ & $2^{-3}$ & $2^{-4}$ & $2^{-5}$ & $2^{-6}$ & $2-7$ & $2^{-8}$ \\
\hline Natrium chloratum & + & + & + & + & + & + & + & + & + \\
\hline Natrium sulfuricum.. & - & + & + & + & + & + & + & + & + \\
\hline Natrium carbonicum. & + & + & + & + & + & + & + & + & + \\
\hline Natrium bicarbonicum...... & + & + & + & + & + & + & + & + & + \\
\hline Natrium citricum neutrale. & - & + & + & + & + & + & + & + & + \\
\hline 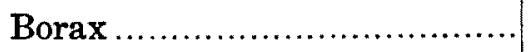 & - & + & + & + & + & + & + & + & + \\
\hline Kalium jodatum.. & + & + & + & + & + & + & + & + & + \\
\hline Kalium citricum... & - & + & + & + & + & + & + & + & + \\
\hline Kalium permanganicum . & - & - & - & - & - & - & - & + & + \\
\hline Argentum nitricum ............. & - & - & - & - & - & - & - & - & - \\
\hline Hydrargyrum bichloratum ... & - & - & - & - & - & - & - & + & + \\
\hline Cuprum sulfuricum ....... & - & - & - & - & - & - & + & + & + \\
\hline Alminium sulfuricum & - & - & - & - & + & + & + & + & + \\
\hline Alumen ....................... & - & - & - & - & - & - & - & + & + \\
\hline Ammonium chloratum..... & + & + & + & + & + & + & + & + & + \\
\hline Ammonium sulfuricum & + & + & + & + & + & + & + & + & + \\
\hline Ammonium oxalicum & - & + & + & + & + & + & + & + & + \\
\hline Ammonium molybdaenicum & - & + & + & + & + & + & + & + & + \\
\hline Barium nitricum & + & + & + & + & + & + & + & + & + \\
\hline Barium chloratum & - & + & + & + & + & + & + & + & + \\
\hline
\end{tabular}

c) Experiments with various kinds of capillary-active-substances.In so far as experiments are concerned (Table IV), such capillary-activesubstances as methyl- and ethyl-alcohols show a little attraction, but chloroform exerts a paramount effect upon the nema, which ceases immediately its motion and discharges its ova, feces, etc.

\section{TABLE IV.}

Effect of various capillary-active-substances on Rhabditis filiformis.

\begin{tabular}{|c|c|c|c|c|}
\hline Concentration (\%) & \multicolumn{4}{|c|}{$5.0 \times$} \\
\hline Chemical & 1 & $2^{-1}$ & $2^{-2}$ & $2^{-3}$ \\
\hline Alcohol methylicus & + & + & + & + \\
\hline Alcohol ethylicus & + & + & + & + \\
\hline Chloroformium ... & - & + & + & + \\
\hline
\end{tabular}


No. 8.] Notes on the Chemotactic Response of Rhabditis filiformis Bütschli.

d). Experiments with various kinds of dyes.-Generally speaking, the nema is of a negative response to various kinds of dyes to a certain extent, as may be seen from Table $V$. No difference can be demonstrated in the response of the nema to acid and basic dyes.

\section{TABLE V.}

Effect of various kinds of dyes on Rhabditis filiformis.

\begin{tabular}{|c|c|c|c|c|c|c|c|c|}
\hline \multirow{2}{*}{ Chemical } & \multicolumn{8}{|c|}{$5.0 \times$} \\
\hline & 1 & $2^{-1}$ & $2-2$ & $2^{-3}$ & $2^{-4}$ & $2^{-6}$ & $2^{-6}$ & $2^{-7}$ \\
\hline Eosin (water soluble) & - & - & - & - & - & + & + & + \\
\hline Congo $\quad .$. & - & - & - & - & - & + & + & + \\
\hline Carmin ....... & - & - & - & + & + & + & + & + \\
\hline Neutral red & - & - & - & - & - & - & - & + \\
\hline Fuchsin & - & - & - & - & + & + & + & + \\
\hline Methylene blue & - & - & - & - & - & - & + & + \\
\hline Gentiana violet & - & - & - & - & + & + & + & + \\
\hline Safranin $\ldots$. & 一 & - & - & - & - & + & + & + \\
\hline Methylene violet & - & - & - & - & - & + & + & + \\
\hline Thionin .... & - & - & - & - & - & + & + & + \\
\hline
\end{tabular}

In conclusion the results obtained are summarized as follows:

(1) Rhabditis filiformis Bütschli is generally attracted to acids more than to alkalies and to inorganic acids more than to organic.

(2) The nema acts independently for most salts, exclusive of such chemicals as kalium permanganicum, argentum nitricum, hydrargyrum bichloratum, alumen and cuprum sulfuricum, to which it shows no attraction at all.

(3) The nema shows a little attraction to such capillary-activesubstances as methyl- and ethyl-alcohols but not to chloroform.

(4) Various kinds of dyes appear to present no attraction. 